\title{
Effects of Fertilizer Placement and Nitrogen Forms on Soil Nitrogen Diffusion and Migration of Red-Yellow Soil in China
}

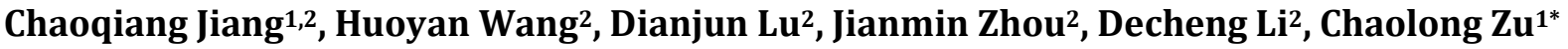 \\ ${ }^{1}$ Tobacco Research Institute/Maize Research Institute, Anhui Academy of Agricultural Sciences, Hefei, China \\ ${ }^{2}$ State Key Laboratory of Soil and Sustainable Agriculture, Institute of Soil Science, Chinese Academy of Sciences, \\ Nanjing, China \\ Email: *1cz2468@sina.com
}

How to cite this paper: Jiang, C.Q., Wang, H.Y., Lu, D.J., Zhou, J.M., Li, D.C. and Zu, C.L. (2017) Effects of Fertilizer Placement and Nitrogen Forms on Soil Nitrogen Diffusion and Migration of Red-Yellow Soil in China. Agricultural Sciences, 8, 1227-1238. https://doi.org/10.4236/as.2017.811088

Received: September 24, 2017 Accepted: November 6, 2017

Published: November 9, 2017

Copyright $\odot 2017$ by authors and Scientific Research Publishing Inc. This work is licensed under the Creative Commons Attribution International License (CC BY 4.0).

http://creativecommons.org/licenses/by/4.0/

\begin{abstract}
A better understanding of nitrogen $(\mathrm{N})$ diffusion and transformation in soils could reveal the capacity of the biological inorganic $\mathrm{N}$ and improve the efficiency of $\mathrm{N}$ fertilizers. A field micro-plot experiment was carried out to study the effects of fertilization methods (mixed uniformly with $12 \mathrm{~cm}$ top soil, placed in holes at a $12-\mathrm{cm}$ depth, or placed in furrows at a $12-\mathrm{cm}$ depth) and forms of $\mathrm{N}$ fertilizers (urea and ammonium phosphate) on the dynamics of soil N's vertical diffusion and horizontal migration in red-yellow soil. The soil inorganic $\mathrm{N}\left(\mathrm{NH}_{4}^{+}-\mathrm{N}\right.$ and $\left.\mathrm{NO}_{3}^{-}-\mathrm{N}\right)$ content following point deep placement was greater than that from mixed or furrow applications. Under point placement, the migration of soil inorganic $\mathrm{N}$ in urea and ammonium phosphate treatments occurred in the $6-15 \mathrm{~cm}$ layer at a horizontal distance of $0-9 \mathrm{~cm}$. However, the nutrient preservation capability of the soil receiving ammonium phosphate was greater than that receiving urea under point deep placement. Thus, point deep placement had a tendency to increase the inorganic $\mathrm{N}$ in the soil and reduce inorganic $\mathrm{N}$ loss, which probably occurred due to the reduced soil volume with which the $\mathrm{N}$ fertilizer was mixed. According to crop growth and fertilizer requirements, the optimized fertilizer placement and $\mathrm{N}$ species resulted in a continuously high nutrient supply to crops for $90 \mathrm{~d}$. However, the effects of point deep placement on increasing the N-use efficiency and reducing $\mathrm{N}$ loss have to be evaluated under natural field conditions.
\end{abstract}

\section{Keywords}

Fertilization Method, Nitrogen Fertilizer, Point Deep Placement, Migration, Transformation 


\section{Introduction}

Inappropriate applications of nitrogen $(\mathrm{N})$ fertilizer have led to low $\mathrm{N}$-use efficiencies (NUEs) and great $\mathrm{N}$ losses [1] [2], and have caused environmental problems, such as groundwater and surface water contamination, greenhouse gas increases, and soil quality degradation [3] [4]. The movement and transformation of $\mathrm{N}$ fertilizers in soils significantly affects the $\mathrm{N}$ supply, NUE and $\mathrm{N}$ loss. Therefore, research has focused on the migration and transformation of $\mathrm{N}$ in soils after fertilization [5] [6] [7]. Wang and Hou [8] reported that the migration of urea in soil was closely related to soil properties (especially the clay content) and the amount of urea applied. Additionally, the migration of $\mathrm{N}$ from urea occurred in a less than 10-cm zone in calcareous soil. Zhang et al. [9] suggested that the migration and transformation of urea and ammonium sulfate mainly occurs in the $0-5 \mathrm{~cm}$ soil layer in a black soil column. Recently, a soil column experiment also found that the transfer and nitrification of $\mathrm{NH}_{4}^{+}-\mathrm{N}$ and $\mathrm{NO}_{3}^{-}-\mathrm{N}$ mainly occurs in the $0-15 \mathrm{~cm}$ and $0-50 \mathrm{~cm}$ layers, respectively, of black soil [10].

The migration and transformation of $\mathrm{N}$ in soil, and the NUE and $\mathrm{N}$ loss, were significantly different under different methods of fertilization. An optimum fertilization model can reduce $\mathrm{N}$ loss, and increase crop yield and the NUE [11] [12] [13]. Rees et al. [11] indicated that $\mathrm{NH}_{4}^{+}-\mathrm{N}$ and $\mathrm{NO}_{3}^{-}-\mathrm{N}$ concentrations in the point-placement (hole-source fertilization) application were significant greater than in the corresponding surface-application and mixed-incorporation treatments. Wang et al. [14] found that point deep placement can reduce the $\mathrm{N}$ fertilizer loss and improve the NUE. The $\mathrm{NH}_{4}^{+}-\mathrm{N}$ was mainly distributed around fertilizer micro-regions and decreased as the distance increased from the point of fertilization [15]. Point deep fertilization can reduce inorganic $\mathrm{N}$ losses compared with mixed and broadcast fertilization [6]. Compared with the surface broadcast, the deep placement of $\mathrm{N}$ fertilizers $(8-10 \mathrm{~cm})$ can enhance the NUE [16], cause roots to grow down [13], and increase crop yields [12].

To improve the NUE and reduce $\mathrm{N}$ loss, previous studies have primarily focused on the application of the right source (or product) at the right rate, right time and right place (four rights, 4R). Based on previous studies, Wang and Zhou [17] recently indicated that the optimal fertilizer placement coordinates its migration with plant root' extension, improving the fertilizer-use efficiency and reducing non-point source pollution in the field. Understanding the migratory abilities and scopes of fertilizer nutrients is the foundation for realizing the coordination of fertilizer migration and root extension. Therefore, it is critically important to understand the characteristics of $\mathrm{N}$ migration to reduce the amount of $\mathrm{N}$ fertilizer used and increase the NUE. In the present study, a field micro-plot experiment was initiated to determine the effects of fertilization methods and forms of $\mathrm{N}$ fertilizers on $\mathrm{N}$ diffusion and migration in red-yellow soil. 


\section{Materials and Methods}

\subsection{Site Description}

The field experiment was conducted at Dongzhi county $\left(30^{\circ} 17^{\prime} \mathrm{N}, 117^{\circ} 4^{\prime} \mathrm{E}\right)$ of Chizhou city, in southern Anhui province, China (Figure 1). The soil at the experimental sites was classified as a red-yellow soil in the Chinese classification system (Chinese Academy of Sciences, 2001). The topsoil $(0-20 \mathrm{~cm})$ has a $\mathrm{pH}$ of 5.7 , an organic matter content of $17.03 \mathrm{~g} / \mathrm{kg}$, a total $\mathrm{N}$ content of $760 \mathrm{mg} / \mathrm{kg}$ and an available $\mathrm{N}$ content of $76.9 \mathrm{mg} / \mathrm{kg}$.

\subsection{Experimental Treatment and Implementation}

The experiment was designed as a split-plot experiment with fertilizer method as the main plot and $\mathrm{N}$ fertilizer form as the split-plot, with three replicates. The fertilizer methods included mixed uniformly with $12 \mathrm{~cm}$ top soil (mixed application), point placement in holes at a depth of $12 \mathrm{~cm}$ (point deep placement), and placed in furrows at $12-\mathrm{cm}$ depths (furrow application). The fertilizers in both the point deep placement and the furrow application treatments were covered with soil and pressed slightly. The two forms of $\mathrm{N}$ fertilizer were urea $(46 \% \mathrm{~N})$ and ammonium phosphate $(21.2 \% \mathrm{~N})$.

The $\mathrm{N}$-fertilizer rate was $180 \mathrm{~kg} / \mathrm{ha}$, which is typical of the farmer's practice in this region. Each microplot measured $140 \times 120 \mathrm{~cm}$. As usual, the maize was planted with an inter-row spacing of $60 \mathrm{~cm}$ and an intra-row spacing of $28 \mathrm{~cm}$ $(60,000 \mathrm{plant} / \mathrm{ha})$ in this region. Thus, for the mixed application, the amounts of urea and ammonium phosphate in each microplot were $65.2 \mathrm{~g}$ and $141.5 \mathrm{~g}$, respectively. For the point deep placement, the microplot was divided into 10 points

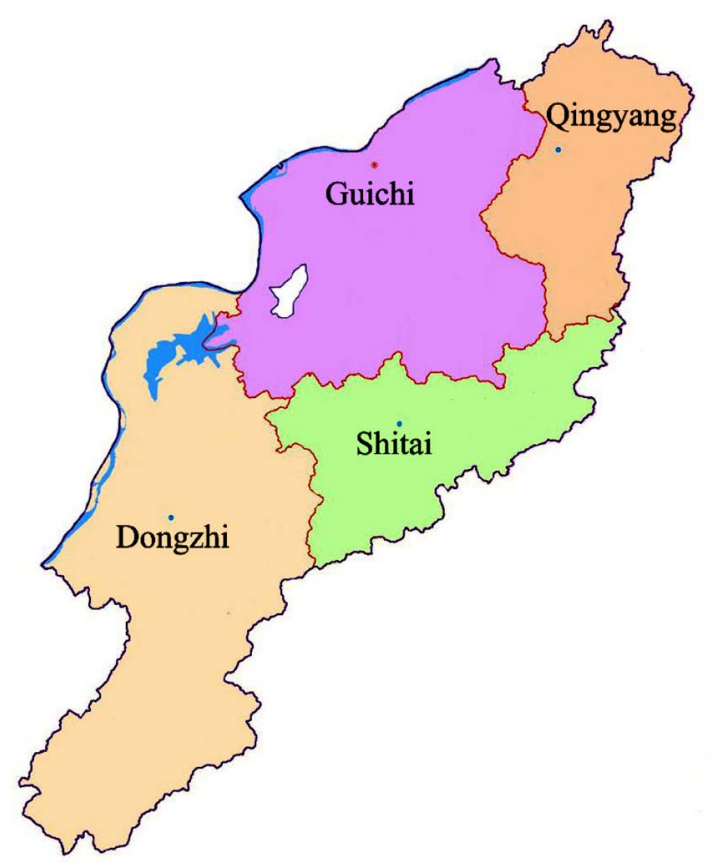

Figure 1. Location of the experimental site at Dongzhi county of Chizhou city. 
sing a $60 \times 28 \mathrm{~cm}$ spacing, and the amounts of urea and ammonium phosphate in each point were $6.52 \mathrm{~g}$ and $14.15 \mathrm{~g}$, respectively. For the furrow application, the fertilizers were equally applied in two $140-\mathrm{cm}$ furrows with a space of $60 \mathrm{~cm}$, and the amounts of urea and ammonium phosphate in each furrow were $32.6 \mathrm{~g}$ and $70.75 \mathrm{~g}$, respectively. During the experiment, no crops were planted, there was no irrigation supplied, and the weeds were removed from the plot. The monthly mean rainfall during the experimental period was 365.5, 259.1 and $137.4 \mathrm{~mm}$ for June, July and August in 2015, respectively.

\subsection{Sample Collection and Measurement}

The topsoil $(0-20 \mathrm{~cm})$ samples were collect in each microplot before fertilization. At 30, 60 and $90 \mathrm{~d}$ after fertilizer application, the soil cores were taken from the placement using a fertilizer soil sampler with a $3-\mathrm{cm}$ diameter, to a depth of $21 \mathrm{~cm}$ and divided into $0-3,3-6,6-9,9-12,12-15,15-18$ and $18-21-\mathrm{cm}$ sections. At the same time, for the point deep placement and furrow-application treatments, the topsoil $(0-21 \mathrm{~cm})$ samples were also collected to an $18-\mathrm{cm}$ horizontal distance away from the fertilization point, and divided into $0-3,3-5,5$ - 7, $7-9,9-12,12-15$ and $15-18$-cm sections.

Soil samples were extracted by using $2 \mathrm{M} \mathrm{KCl}$, and the ammonium $\mathrm{N}\left(\mathrm{NH}_{4}^{+}-\mathrm{N}\right)$ and nitrate $\mathrm{N}\left(\mathrm{NO}_{3}^{-}-\mathrm{N}\right)$ were determined using an automated discrete analyzer (Smart Chem 200, AMS/Westco, Italy) as described by Ling et al. [6].

\subsection{Statistical Analysis}

The statistical analysis was carried out using SPSS 19.0 statistical software (SPSS, Inc., Chicago, IL, USA), and data were presented as the mean \pm SE. All of the experiments included three replicates.

\section{Results}

\subsection{Soil $\mathrm{NH}_{4}^{+}-\mathrm{N}$ Content for Different Fertilization Methods}

The $\mathrm{NH}_{4}^{+}-\mathrm{N}$ content in different soil layers for all treatments during the experimental period is shown in Figure 2. During the mixed application and furrow application, $\mathrm{NH}_{4}^{+}-\mathrm{N}$ levels in soil were lower than $30 \mathrm{mg} / \mathrm{kg}$, and decreased as the soil depth increased. As expected, point deep placement resulted in a greater $\mathrm{NH}_{4}^{+}-\mathrm{N}$ content in the soil than that of the mixed and furrow applications, particularly at 30 and $60 \mathrm{~d}$ after the treatment. Although the $\mathrm{NH}_{4}^{+}-\mathrm{N}$ contents in the point deep placement layers decreased gradually during the treatment, in the 9 - 12-cm layer, the $\mathrm{NH}_{4}^{+}-\mathrm{N}$ content in the soil was 472,142 and $21 \mathrm{mg} / \mathrm{kg}$ on 30,60 and $90 \mathrm{~d}$, respectively. These values were greater than those of the mixed and furrow applications.

For the horizontal migration of $\mathrm{N}$, throughout the experiment, the soil $\mathrm{NH}_{4}^{+}-\mathrm{N}$ content of the point deep placement application was greater than that of the furrow application within $9 \mathrm{~cm}$ of the fertilizer placement site (Figure 3 ). 

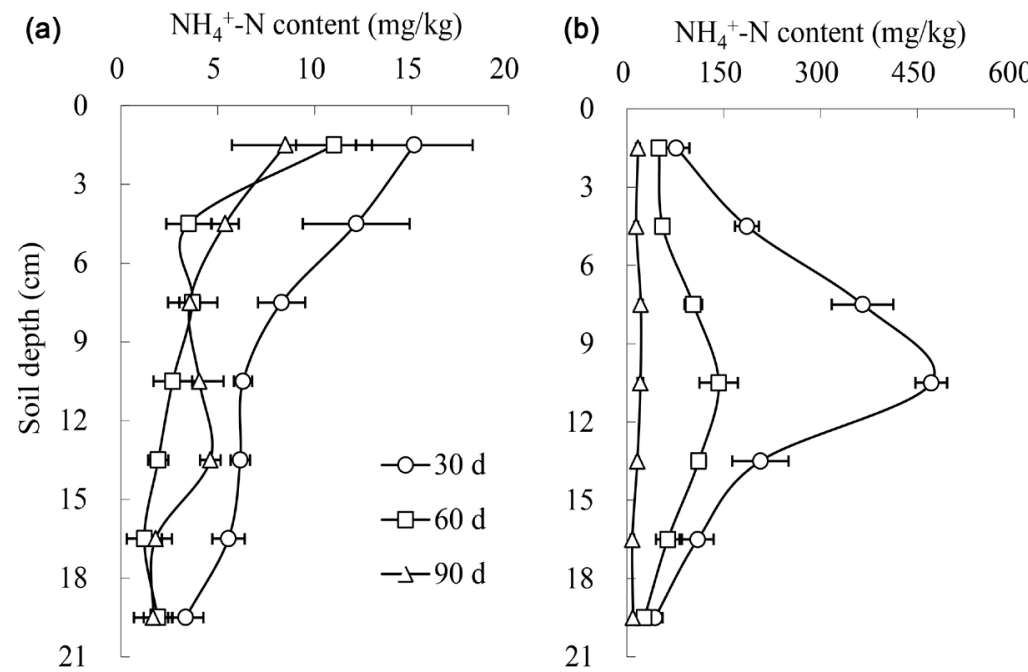

$\begin{array}{ccccc}\text { (c) } & \mathrm{NH}_{4}{ }^{+}-\mathrm{N} \text { content }(\mathrm{mg} / \mathrm{kg}) \\ 0 & 10 & 20 & 30 & 40 \\ 0 & & & \end{array}$

Figure 2. Dynamic changes of soil $\mathrm{NH}_{4}^{+}-\mathrm{N}$ content under different fertilization methods (vertical direction). (a) mixed uniformly with $12 \mathrm{~cm}$ top soil (mixed application), (b) placed in holes at 12-cm depth (point deep placement), (c) placed in furrows at $12-\mathrm{cm}$ depth (furrow application).
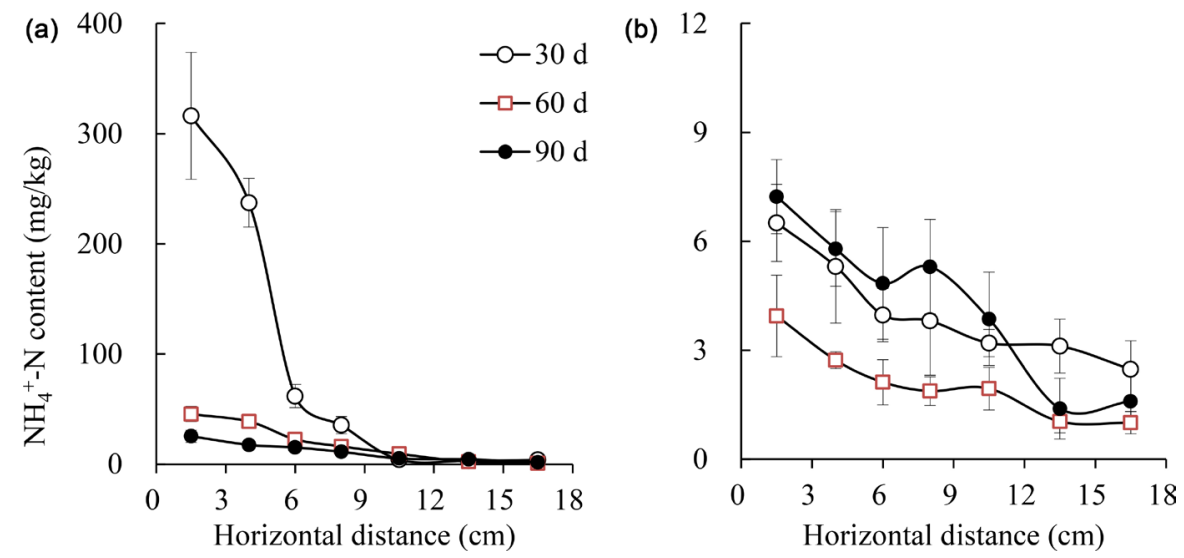

Figure 3. Dynamic changes of soil $\mathrm{NH}_{4}^{+}-\mathrm{N}$ content under different fertilization methods (horizontal direction). (a) placed in holes at 12-cm depth (point deep placement), (b) placed in furrows at $12-\mathrm{cm}$ depth (furrow application).

The soil $\mathrm{NH}_{4}^{+}-\mathrm{N}$ content of point deep placement application at $7-9 \mathrm{~cm}$ from the fertilizer placement site was 8.3, 7.6 and 1.1 times greater than that of the furrow application on 30, 60 and $90 \mathrm{~d}$, respectively. The differences in the soil $\mathrm{NH}_{4}^{+}-\mathrm{N}$ content between the point deep placement and furrow applications increased as the distance from fertilizer placement site decreased. The migration (horizontal distance) of urea in the point deep placement was $\sim 7-9 \mathrm{~cm}$, and the soil $\mathrm{NH}_{4}^{+}-\mathrm{N}$ content was mainly concentrated in the $3-18-\mathrm{cm}$ layer.

\subsection{Soil $\mathrm{NO}_{3}^{-}-\mathrm{N}$ Content for Different Fertilization Methods}

Throughout the study period, the soil $\mathrm{NO}_{3}^{-}-\mathrm{N}$ contents in different layers were greater in the point deep placement application than in the mixed and furrow applications (Figure 4). In all of the treatments, the soil $\mathrm{NO}_{3}^{-}-\mathrm{N}$ content was 
greatest in the $0-3 \mathrm{~cm}$ layer at $30 \mathrm{~d}$ and $60 \mathrm{~d}$, and decreased as the soil depth increased. However, the soil $\mathrm{NO}_{3}^{-}-\mathrm{N}$ content was greatest in the $3-6-\mathrm{cm}$ layer at $90 \mathrm{~d}$ in all of the treatments. For the point deep placement, the soil $\mathrm{NO}_{3}^{-}-\mathrm{N}$ content was higher in the $0-9-\mathrm{cm}$ layer than at the fertilization point $(9-12-\mathrm{cm}$ layer). Thus, the soil $\mathrm{NO}_{3}^{-}-\mathrm{N}$ content had a tendency to migrate to the soil surface during the treatment.

For the horizontal distance, the soil $\mathrm{NO}_{3}^{-}-\mathrm{N}$ content was greater in the point deep placement than in the furrow application within $12 \mathrm{~cm}$ from the fertilizer placement site during the $90 \mathrm{~d}$ of treatment (Figure 5). The migration (horizontal distance) of urea from the point deep placement was $\sim 10 \mathrm{~cm}$, and the soil $\mathrm{NO}_{3}^{-}-\mathrm{N}$ content sharply decreased from $0 \mathrm{~cm}$ to $18 \mathrm{~cm}$ away from the fertilizer placement site.

(a)

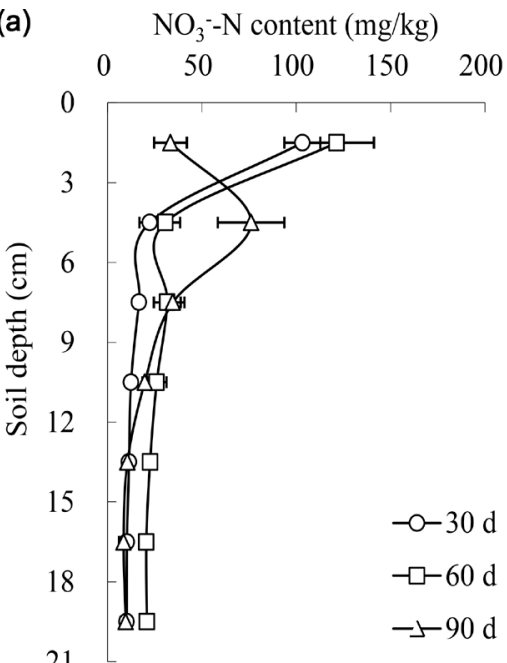

(b)

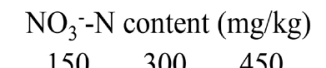

\section{0}
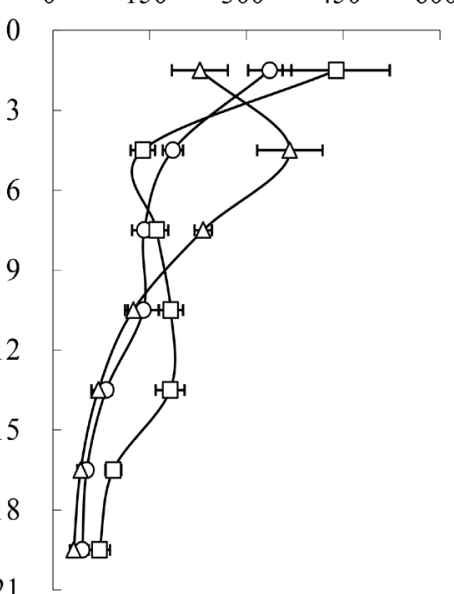

(c) $\quad \mathrm{NO}_{3}^{-}-\mathrm{N}$ content $(\mathrm{mg} / \mathrm{kg})$

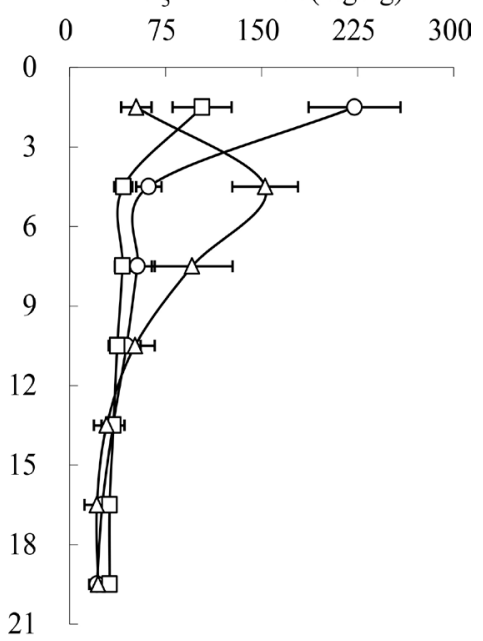

Figure 4. Dynamic changes of soil $\mathrm{NO}_{3}^{-}-\mathrm{N}$ content under different fertilization methods (vertical direction). (a) mixed uniformly with $12 \mathrm{~cm}$ top soil (mixed application), (b) placed in holes at 12-cm depth (point deep placement), (c) placed in furrows at 12 -cm depth (furrow application).
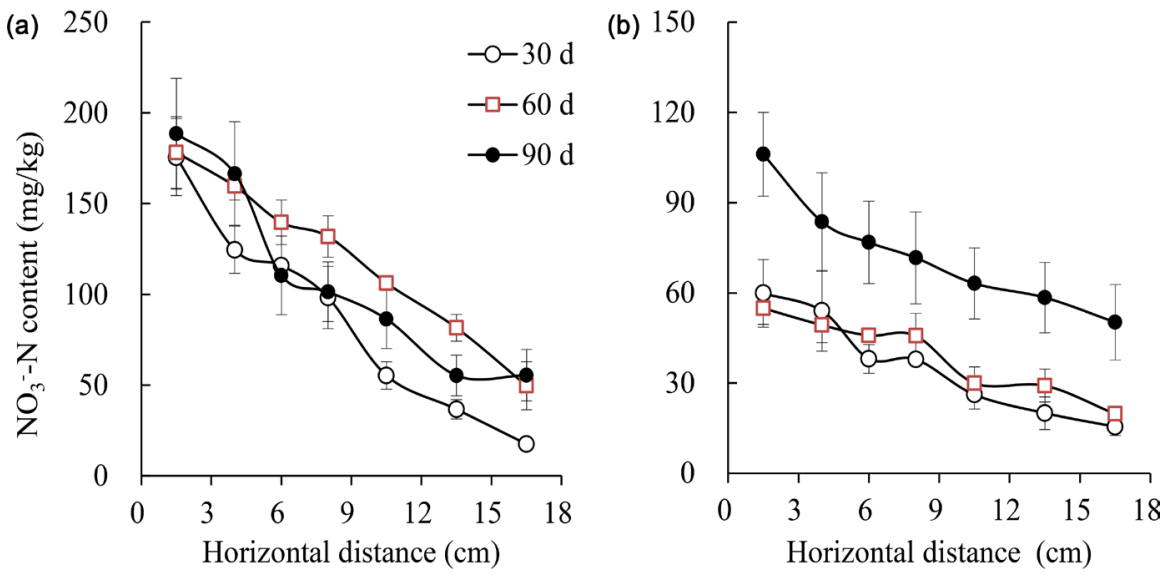

Figure 5. Dynamic changes in the soil $\mathrm{NO}_{3}^{-}-\mathrm{N}$ content under different fertilization methods (horizontal direction). (a) placed in holes at 12-cm depth (point deep placement), (b) placed in furrows at $12-\mathrm{cm}$ depth (furrow application). 


\subsection{Soil inorganic N Content for Different N Forms in the Point Deep Placement}

Under the point deep placement conditions, the soil inorganic $\mathrm{N}\left(\mathrm{NH}_{4}^{+}-\mathrm{N}+\right.$ $\left.\mathrm{NO}_{3}^{-}-\mathrm{N}\right)$ content near the fertilization point $(9-18 \mathrm{~cm}$ layer) was greater with the ammonium phosphate treatment than with the urea treatment (Figure 6). However, the inorganic $\mathrm{N}$ levels were greater in the topsoil $(0-3 \mathrm{~cm})$ with the urea treatment than with the ammonium phosphate treatment at both $60 \mathrm{~d}$ and $90 \mathrm{~d}$. As expected, on $30 \mathrm{~d}$, the greatest inorganic $\mathrm{N}$ content was observed at the fertilization point ( $9-12 \mathrm{~cm}$ layer) for both the urea and ammonium phosphate treatments (612 and $779 \mathrm{mg} / \mathrm{kg}$, respectively). Conversely, on $90 \mathrm{~d}$, the inorganic $\mathrm{N}$ levels were greatest in the $3-6 \mathrm{~cm}$ layer for both urea and ammonium phosphate treatments ( 382 and $329 \mathrm{mg} / \mathrm{kg}$, respectively), and decreased as soil profile's depth increased.

For horizontal distance, the inorganic $\mathrm{N}$ content was greater with the ammonium phosphate treatment than with the urea treatment within $6 \mathrm{~cm}$ of the fertilizer placement site (Figure 7). However, the gap in the inorganic $\mathrm{N}$ content between the ammonium phosphate and urea treatments decreased as the horizontal distance increased, and the inorganic $\mathrm{N}$ levels at $15-18 \mathrm{~cm}$ away from the fertilization site were similar in the two treatments (57 and $59 \mathrm{mg} / \mathrm{kg}$ urea and ammonium phosphate, respectively).

\section{Discussion}

In the present study, the soil inorganic $\mathrm{N}$ content was strongly affected by the $\mathrm{N}$ application method. The soil $\mathrm{NH}_{4}^{+}-\mathrm{N}$ and $\mathrm{NO}_{3}^{-}-\mathrm{N}$ contents with the point deep placement application were greater than those of the mixed and furrow applications, and the difference in the soil inorganic $\mathrm{N}$ content between the point deep placement and the mixed or the application was more apparent in the $6-15$
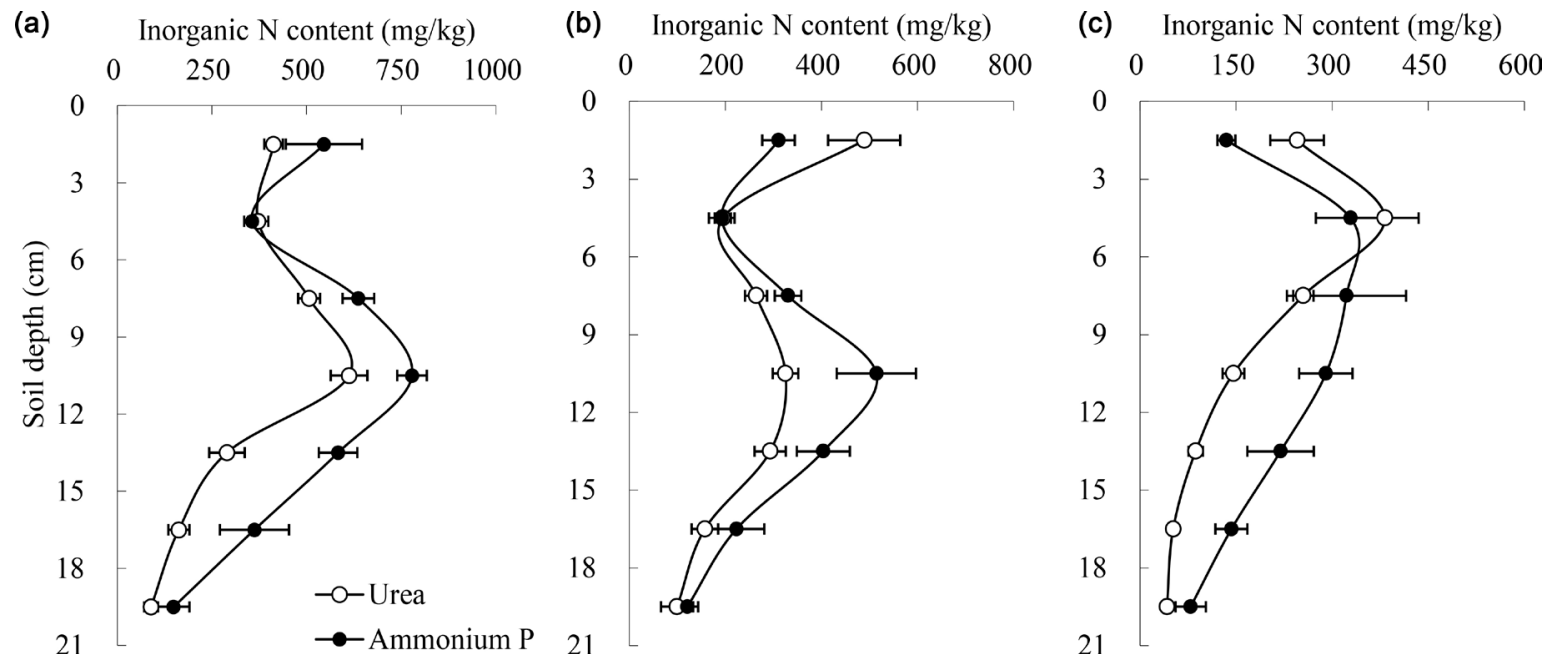

Figure 6. Effects of different nitrogen (N) fertilizers on inorganic $\mathrm{N}\left(\mathrm{NH}_{4}^{+}-\mathrm{N}+\mathrm{NO}_{3}^{-}-\mathrm{N}\right)$ contents in soils after a point deep placement (vertical direction) treatment. (a) $30 \mathrm{~d}$, (b) $60 \mathrm{~d}$ and (c) $90 \mathrm{~d}$. 

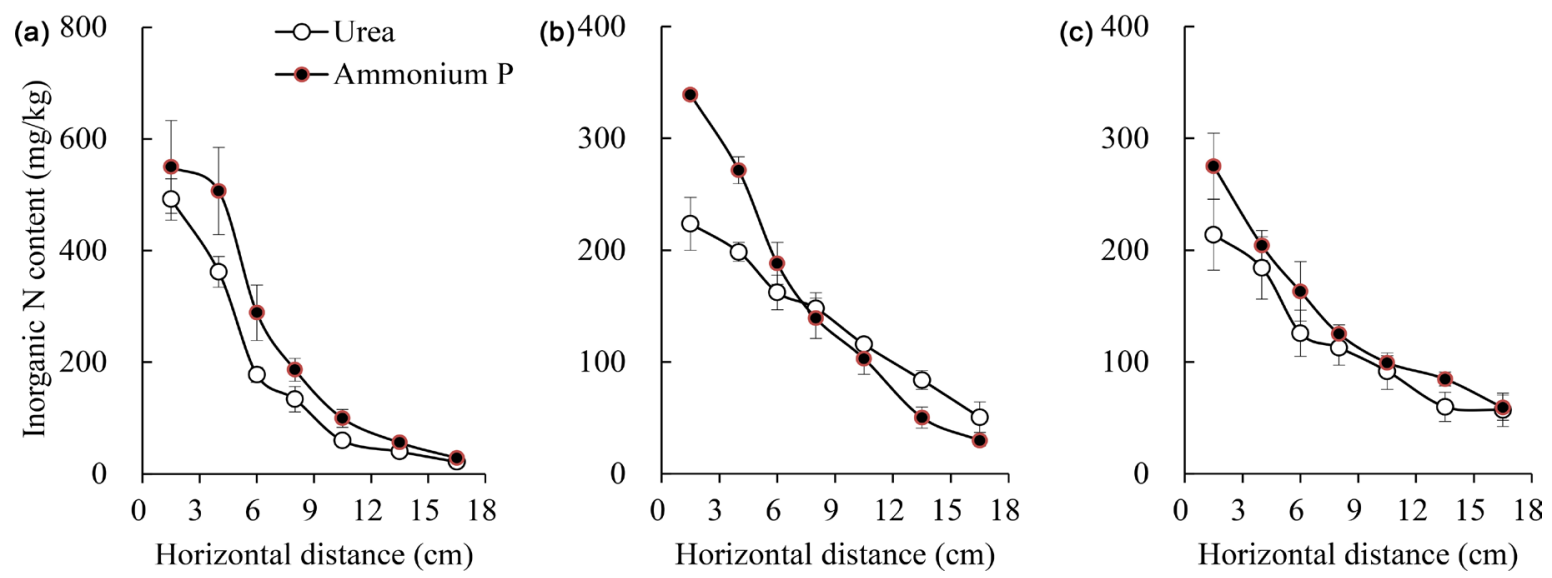

Figure 7. Effects of different nitrogen (N) fertilizers on the inorganic $\mathrm{N}\left(\mathrm{NH}_{4}^{+}-\mathrm{N}+\mathrm{NO}_{3}^{-}-\mathrm{N}\right)$ contents in soils after a point deep placement (horizontal direction) treatment. (a) $30 \mathrm{~d}$, (b) $60 \mathrm{~d}$ and (c) $90 \mathrm{~d}$.

layers and the horizontal distance of $0-9 \mathrm{~cm}$. Similarly, Ling et al. [6] found that the inorganic $\mathrm{N}$ concentration in the $6-16 \mathrm{~cm}$ layers of paddy soil showed the following sequence: point deep fertilization $>$ mixed fertilization with $3 \%$ soil $>$ mixed fertilization with $10-\mathrm{cm}$ top soil $>$ broadcast. Rees et al. [11] showed that the mineral nitrogen $\left(\mathrm{NH}_{4}^{+}-\mathrm{N}+\mathrm{NO}_{3}^{-}-\mathrm{N}\right)$ contents in soil of point deep placement applications were much greater than those of surface applications. Cheng et al. [15] found that $\mathrm{NH}_{4}^{+}-\mathrm{N}$ was mainly distributed around the film hole and decreased as the distance from film hole increased after film hole irrigation with urea solution. The greater concentration of soil inorganic $\mathrm{N}$ in the point deep placement was probably due to the decrease in the initial soil volume with which the $\mathrm{N}$ fertilizers were mixed [6]. This is shown by the greater yields and NUEs after large particles of urea were applied compared with small particles of urea in rice field experiments [18]. Moreover, under the point deep placement application, the urea was buried beneath the soil and the ammonia volatilization occurred at a much slower rate than that in the mixed or furrow application [19] [20]. Recently, our research group found that $\mathrm{N}$ fertilizer applied in bands increased grain yields by $15 \%$ compared with a broadcast application, and the banded placement of $\mathrm{N}$ fertilizer decreased the $\mathrm{N}$ loss in the wheat-soil system [21]. Thus, the smaller the initial soil volume with which the $\mathrm{N}$ fertilizers were mixed, the greater the inorganic $\mathrm{N}$ content achieved in the soil and the less inorganic $\mathrm{N}$ was lost.

The migration and transformation of $\mathrm{N}$ fertilizer were significantly affected by fertilization methods, which resulted in different levels of $\mathrm{N}$ nutrients in the soil profile. In this study, the topsoil $(0-6 \mathrm{~cm})$ had more $\mathrm{NO}_{3}^{-}-\mathrm{N}$ than the deeper $(9-21 \mathrm{~cm})$ soil layer, and the soil $\mathrm{NO}_{3}^{-}-\mathrm{N}$ content decreased as the soil depth increased within $21 \mathrm{~cm}$ during the 60 days after fertilization. Even at 90 days after treatment, the $\mathrm{NO}_{3}^{-}-\mathrm{N}$ contents in the $0-6 \mathrm{~cm}$ layers were still at high levels. The $\mathrm{NO}_{3}^{-}-\mathrm{N}$ levels were greater in topsoil than in the deeper soil layer possibly because the $\mathrm{N}$ fertilizer had a tendency to migrate to the soil surface. 
During the dry season, the soil water evaporation was greater than the rainfall (data not shown), and the soil water in the deep layer moved to the surface easier. Therefore, the $\mathrm{N}$ fertilizer was likely to be carried to the soil surface by the soil water. In addition, the migratory ability of $\mathrm{NH}_{4}^{+}-\mathrm{N}$ in soil following a point deep placement was weaker than that of $\mathrm{NO}_{3}^{-}-\mathrm{N}$, whereas there was a sharper reduction in $\mathrm{NH}_{4}^{+}-\mathrm{N}$ than in $\mathrm{NO}_{3}^{-}-\mathrm{N}$. Jarvis et al. [22] showed that the water potential in the soil may reduce mineralization and $\mathrm{NH}_{4}^{+}-\mathrm{N}$ levels because of the limitations of biological activities. Here, the low soil water content may limit solute diffusion and the transportation of $\mathrm{N}$ fertilizer, particularly for $\mathrm{NH}_{4}^{+}-\mathrm{N}$. Similar observations have been found in previous studies [23]. Higher levels of $\mathrm{NH}_{4}^{+}-\mathrm{N}$ and $\mathrm{NO}_{3}^{-}-\mathrm{N} 90$ days after the point deep placement application can provide the $\mathrm{N}$ nutrients needed during the growth periods of most crops. Thus, a continuously high concentration of nutrients for crops could be supplied by optimizing fertilizer placement.

$\mathrm{N}$ migration and transformation vary with fertilizer type, which will result in different impacts on the soil inorganic $\mathrm{N}$ content. Under point deep placement, the migration of soil inorganic $\mathrm{N}$ in urea and ammonium phosphate treatments occurred in the $6-15-\mathrm{cm}$ layers and the horizontal distance of $0-9 \mathrm{~cm}$. The soil inorganic $\mathrm{N}$ had a tendency to migrate to the soil surface during the treatment. For example, the highest soil inorganic $\mathrm{N}$ content was observed in the $3-6-\mathrm{cm}$ layer for both urea $(382 \mathrm{mg} / \mathrm{kg})$ and ammonium phosphate $(329 \mathrm{mg} / \mathrm{kg})$ treatments at $90 \mathrm{~d}$. Thus, the migratory distances of both urea and ammonium phosphate were $\sim 6 \mathrm{~cm}$ and $9 \mathrm{~cm}$ in the vertical and horizontal directions, respectively, within $90 \mathrm{~d}$. According to Zhang et al. [9], the migration and transformation of $\mathrm{N}$ mainly occur in the 0 - 5-cm soil layer, and the $\mathrm{N}$ transformation rate of urea is greater than that of ammonium sulfate. However, Wang and Hou [8] observed that the migration of urea in Fluvo-aquic soils was $\sim 10 \mathrm{~cm}$ from the fertilizer placement site, and the migratory distance of urea was strongly related to the soil properties (especially the clay content) and fertilizer rates. Similarly, the migratory distances of urea and ammonium phosphate with a point deep placement were mainly within $10 \mathrm{~cm}$, and the horizontal movement distance from the fertilizer site was $\sim 5-7 \mathrm{~cm}$ after $90 \mathrm{~d}$.

In addition, the soil inorganic $\mathrm{N}$ content was greater with the ammonium phosphate treatment than with the urea treatment, except for the topsoil $(0-6$ $\mathrm{cm}$ layer), especially in $9-15 \mathrm{~cm}$ layer. The soil inorganic $\mathrm{N}$ content of the ammonium phosphate treatment was significant greater than that of the urea treatment at 30,60 and $90 \mathrm{~d}$. Thus, ammonium phosphate had a greater capacity than urea to maintain a high inorganic $\mathrm{N}$ content in soil under point deep placement. A possible explanation for the lower inorganic $\mathrm{N}$ content following urea applications is that urea may be quickly converted to ammonium $\mathrm{N}$ after being applied to the soil, leading to an increase in $\mathrm{NH}_{3}$ volatilization [8]. However, Ling et al. [6] observed no significant difference in the nutrient-retaining property between urea and ammonium phosphate treatments in paddy soil. This 
may be related to a high soil water content because in flooded paddy soil not only can the $\mathrm{NH}_{4}^{+}-\mathrm{N}$ penetrate deeply into the soil by mass flow [24], but $\mathrm{NH}_{4}^{+}-\mathrm{N}$ may also be lost by $\mathrm{NH}_{3}$ volatilization [25]. Xiao et al. [25] found that in paddy fields the total amount of $\mathrm{NH}_{3}$ volatilization ranged from 31.67 to 69.70 $\mathrm{kg} / \mathrm{ha}$ in the whole growth period, accounting for $17.95 \%-28.64 \%$ of applied $\mathrm{N}$. In contrast, in the present study, ammonium phosphate was buried in the dry land, most of the ammonia-based $\mathrm{N}$ was trapped in the soil, and less ammonia escaped to the atmosphere than in the flooded paddy soil. Thus, the higher soil inorganic $\mathrm{N}$ content was maintained. With the point deep placement application method, the urea and ammonium phosphate were buried beneath the soil, and ammonia volatilization occurred at a much slower rate than in the mixed and furrow applications [20]. Thus, fertilizer placement is an important way to improve the nutrient preserving capability of soil.

\section{Conclusion}

Under point deep placement (placed in holes at a 12-cm depth), the migration of soil inorganic $\mathrm{N}$ in urea and ammonium phosphate treatments occurred in the 6 $-15 \mathrm{~cm}$ layer at a horizontal distance of $0-9 \mathrm{~cm}$. The nutrient preservation capability of soil treated with ammonium phosphate was greater than that treated with urea. The point deep placement of $\mathrm{N}$ fertilizer helped to increase the $\mathrm{NH}_{4}^{+}-\mathrm{N}$ and $\mathrm{NO}_{3}^{-}-\mathrm{N}$ contents in red-yellow soil, suggesting that point deep placement had a tendency to increase inorganic $\mathrm{N}$ in soil and reduce inorganic $\mathrm{N}$ loss probably due to the reduced initial volume of the soil with which the fertilizer $\mathrm{N}$ was mixed. Based on crop growth and fertilizer requirements, a single basal application could supply a continuously high concentration of nutrients to the crop for 90 days through the optimization of the fertilizer placement and $\mathrm{N}$ species.

\section{Acknowledgements}

This research was supported by the National Basic Research Program of China (2013CB127401), the Natural Science Foundation of Anhui Province (1708085MC54), and the Discipline Construction Project of Anhui Academy of Agricultural Sciences (17A0921).

\section{References}

[1] Wang, S.J., Luo, S.S., Yue, S.C., Shen, Y.F. and Li, S.Q. (2016) Fate of ${ }^{15} \mathrm{~N}$ Fertilizer under Different Nitrogen Split Applications to Plastic Mulched Maize in Semiarid Farmland. Nutrient Cycling in Agroecosystems, 105, 129-140. https://doi.org/10.1007/s10705-016-9780-3

[2] Zhu, Z. and Chen, D. (2002) Nitrogen Fertilizer Use in China-Contributions to Food Production, Impacts on the Environment and Best Management Strategies. Nutrient Cycling in Agroecosystems, 63, 117-127. https://doi.org/10.1023/A:1021107026067

[3] Davidson, E.A. (2009) The Contribution of Manure and Fertilizer Nitrogen to Atmospheric Nitrous Oxide since 1860. Nature Geoscience, 2, 659-662. 
https://doi.org/10.1038/ngeo608

[4] Reay, D.S., Davidson, E.A., Smith, K.A., Smith, P., Melillo, J.M., et al. (2002) Global Agriculture and Nitrous Oxide Emissions. Nature Climate Change, 2, 410-416. https://doi.org/10.1038/nclimate1458

[5] Kettering, J., Ruidisch, M., Gaviria, C., Ok, Y.S. and Kuzyakov, Y. (2013) Fate of Fertilizer ${ }^{15} \mathrm{~N}$ in Intensive Ridge Cultivation with Plastic Mulching under a Monsoon Climate. Nutrient Cycling in Agroecosystems, 95, 57-72. https://doi.org/10.1007/s10705-012-9548-3

[6] Ling, D., Li, T., Wang, H.Y., Liu, X.W., Chen, Z.M., et al. (2015) Effects of Fertilization Methods and Forms of Nitrogen Fertilizers on Nitrogen Diffusion and Migration in Paddy Soil. Soils, 47, 478-482.

[7] Sommer, S.G., Génermont, S., Cellier, P., Hutchings, N., Olesen, J.E., et al. (2003) Processes Controlling Ammonia Emission from Livestock Slurry in the Field. $E u$ ropean Journal of Agronomy, 19, 465-486.

[8] Wang, S. and Hou, Y. (2004) Changes of Soil Properties in the Courses of Urea Patch Diffusion. Journal of Agro-Environmental Science, 23, 263-266.

[9] Zhang, C., Che, Y.P. and Li, Z.P. (2010) Migration and Transformation of Fertilizer Nitrogen in a Simulated Black Soil Column. Chinese Journal of Eco-Agriculture, 18, 683-688. https://doi.org/10.3724/SP.J.1011.2010.00683

[10] Hu, X.H., Zhou, J.C., Wang, Q.H. and Wang, X.C. (2015) Effects of Temperature, Water Content, and Fertilization on Transformation and Transportation of Nitrogen in the Black Soil with Sugar Beet (Beta vulgaris L.). Journal of Soil and Water Conservation, 29, 82-88.

[11] Rees, R.M., Roelcke, M., Li, S.X., Wang, X.Q., Li, S.Q., et al. (1997) The Effect of Fertilizer Placement on Nitrogen Uptake and Yield of Wheat and Maize in Chinese Loess Soils. Nutrient Cycling in Agroecosystems, 47, 81-91. https://doi.org/10.1007/BF01985721

[12] Yang, Y.M., Sun, Y.M., Jia, L.L., Meng, C.X. and Jia, S.L. (2016) Effect of Base Nitrogen Application Depth on Summer Maize Yield, Nitrogen Utilization Efficiency and Nitrogen Residue. Journal of Plant Nutrition and Fertilizer, 22, 830-837.

[13] Yu, X.F., Gao, J.L., Ye, J., Wang, Z.G., Sun, J.Y., et al. (2013) Effects of Deep Loosening with Nitrogen Deep Placement on Root Growth, Grain Yield and Nitrogen Use Efficiency of Super High-Yield Spring Maize. Journal of Maize Sciences, 21, 114-119.

[14] Wang, X.H., Liu, J. and Wang, Y.Q. (2002) Soil Nitrogen Transport Characteristics under Different Fertilizer Application Practice. Chinese Journal of Soil Science, 33, 202-206.

[15] Cheng, D.J., Zhao, X.Y. and Fei, L.J. (2009) Laboratory Simulation Experiment on Nitrogen Transformation and Distribution under Condition of Film Hole Irrigation with Urea Solution. Transactions of the CSAE, 25, 58-62.

[16] Li, W.B., Li, Y.D. and Wang, H. (2001) Application and Recovery of ${ }^{15} \mathrm{~N}$ Fertilizer for Spring Maize in Black of Jilin. Acta Pedologica Sinica, 38, 476-482.

[17] Wang, H.Y. and Zhou, J.M. (2013) Root-Zone Fertilization-A Key and Necessary Approach to Improve Fertilizer Use Efficiency and Reduce Non-Point Source Pollution from the Cropland. Soils, 45, 785-790.

http://soils.issas.ac.cn/tr/ch/reader/create_pdf.aspx?file_no $=\operatorname{tr} 201305128 \& f l a g=1 \& \mathrm{kj}$ ournal_id=tr\&year_id=2013

[18] Hu, C.H., Luo, G.B., Zeng, J.H. and Pan, X.Z. (2011) Influence of Different Types of 
Slow-Release Nitrogen Fertilizer on Rice Yield and Nitrogen Fertilizer Use Efficiency. Chinese Agricultural Science Bulletin, 27, 174-177.

http://www.casb.org.cn/casb/ch/reader/view_abstract.aspx?pcid=03F54A49DE0057 8AA0E5DDF5BC021AA7\&cid=22643976039EC9DE\&jid=5E9CCDE71739C40FFE5 0EEC7670185A4\&aid=A09F1D21AAC66A2D7D8ABB62C21F2E27\&yid=9377ED8 094509821\&vid=DB817633AA4F79B9\&iid=23CCDDCD68FFCC2F\&sid=0584DB4 87B4581F4\&eid=6425DAE0271BB751\&referenced_num $=2 \&$ reference_num $=14$

[19] Liu, T.Q., Fan, D.J., Zhang, X.X., Chen, J., Li, C.F., et al. (2015) Deep Placement of Nitrogen Fertilizers Reduces Ammonia Volatilization and Increases Nitrogen Utilization Efficiency in No-Tillage Paddy Fields in Central China. Field Crops Research, 184, 80-90.

[20] Prasertsak, P., Freney, J.R., Denmead, O.T., Saffigna, P.G., Prove, B.G., et al. (2002) Effect of Fertilizer Placement on Nitrogen Loss from Sugarcane in Tropical Queensland. Nutrient Cycling in Agroecosystems, 62, 229-239.

https://doi.org/10.1023/A:1021279309222

[21] Chen, Z.M., Wang, H.Y., Liu, X.W., Liu, Y.Z., Gao, S.S., et al. (2016) The Effect of N Fertilizer Placement on the Fate of urea- ${ }^{15} \mathrm{~N}$ and Yield of Winter Wheat in Southeast China. PLoS ONE, 11, e0153701. https://doi.org/10.1371/journal.pone.0153701

[22] Jarvis, S.C., Stockdale, E.A., Shepherd, M.A. and Powlson, D.S. (1996) Nitrogen Mineralization in Temperate Agricultural Soils: Processes and Measurement. Advances in Agronomy, 57, 187-235.

[23] López-Bellido, L., Muñoz-Romero, V., Fernández-García, P. and López-Bellido, R.J. (2014) Ammonium Accumulation in Soil: The Long-Term Effects of Tillage, Rotation and $\mathrm{N}$ Rate in a Mediterranean Vertisol. Soil Use and Management, 30, 471-479. https://doi.org/10.1111/sum.12147

[24] Sun, X.T. (1987) The Trend of ${ }^{15} \mathrm{~N}$-Labeled Urea Applied to Wetland Rice Soil and Its Effect. Soils, 19, 177-182.

http://soils.issas.ac.cn/tr/ch/reader/create_pdf.aspx?file_no=19870402\&flag=1\&jour nal_id=tr\&year_id=1987

[25] Xiao, X., Yang, L.L., Deng, Y.P. and Wang, J.F. (2012) Effects of Irrigation and Nitrogen Fertilization on Ammonia Volatilization in Paddy Field. Journal of Agro-Environment Science, 31, 2066-2071.

http://www.aes.org.cn/nyhjkxxb/ch/reader/create_pdf.aspx?file_no=12478\&flag=1\& journal_id=nyhjkxxb\&year_id=2012 